\title{
Synthesis, Inhibition of Mycobacterium tuberculosis Enoyl-acyl Carrier Protein Reductase and Antimycobacterial Activity of Novel Pentacyanoferrate(II)-isonicotinoylhydrazones
}

\author{
Thais P. Gazzi, ${ }^{\#, a}$ Mariane Rotta, ${ }^{\#, a, b}$ Anne D. Villela, ${ }^{a, b}$ Valnês Rodrigues-Junior, ${ }^{a, c}$ \\ Leonardo K. B. Martinelli, ${ }^{a, c}$ Francisco Adilson M. Sales, ${ }^{d}$ Eduardo Henrique Silva de Sousa, ${ }^{a, d}$ \\ Maria Martha Campos, ${ }^{a, b, c}$ Luiz Augusto Basso, ${ }^{a, b, c}$ Diógenes S. Santos ${ }^{*, a, b}$ and \\ Pablo Machado $*, a, c$ \\ ${ }^{a}$ Centro de Pesquisas em Biologia Molecular e Funcional, \\ Instituto Nacional de Ciência e Tecnologia em Tuberculose, \\ ${ }^{b}$ Programa de Pós-Graduação em Medicina e Ciências da Saúde and \\ 'Programa de Pós-Graduação em Biologia Celular e Molecular, \\ Pontifícia Universidade Católica do Rio Grande do Sul, 90619-900 Porto Alegre-RS, Brazil \\ ${ }^{d}$ Departamento de Química Orgânica e Inorgânica, Universidade Federal do Ceará, \\ 60440-900 Fortaleza-CE, Brazil
}

\begin{abstract}
Tuberculosis remains among the top causes of death triggered by a single pathogen. Herein, a greener synthetic approach for isonicotinoylhydrazones is described using ultrasound energy. These compounds were used as starting materials for synthesizing pentacyanoferrate(II)isonicotinoylhydrazones, which inhibited the reaction catalyzed by Mycobacterium tuberculosis 2-trans-enoyl-ACP $(\mathrm{CoA})$ reductase $(M t \mathrm{InhA})$ in a time-dependent manner. The most active coordination complex showed an increase of more than ten-fold in the $M t \operatorname{InhA}$ inhibition rate constant compared with lead pentacyano(isoniazid)ferrate(II) (IQG607). Additionally, the new series of metal-based compounds demonstrated antitubercular activity against a drug-susceptible Mycobacterium tuberculosis (Mtb) strain and was devoid of toxicity to mammalian cells ( $\mathrm{IC}_{50}>20 \mu \mathrm{mol} \mathrm{L}{ }^{-1}$, half maximal inhibitory concentration). Finally, one of the synthesized compounds showed intracellular activity similar to isoniazid in a macrophage model of Mtb infection, indicating that this chemical class may furnish novel structures to embark on the preclinical phase of anti-tuberculosis drug development.
\end{abstract}

Keywords: metallodrugs, tuberculosis, isoniazid, coordination complex

\section{Introduction}

Tuberculosis (TB) is an infectious disease caused mainly by Mycobacterium tuberculosis (Mtb). As reported by the World Health Organization (WHO), 9.6 million new cases of the disease and 1.5 million deaths were estimated worldwide in 2014. ${ }^{1}$ A complicating factor in controlling this epidemic has been the emergence and spread of multidrug and extensively resistant Mtb strains (MDR and XDR, respectively). ${ }^{1}$ Patients with susceptible TB are treated with isoniazid (INH), rifampicin, ethambutol and pyrazinamide, which form the basis of first-line drug therapy. However, the treatment of drug-resistant TB requires second-line drugs,

\footnotetext{
*e-mail: diogenes@pucrs.br; pablo.machado@pucrs.br
}

\#These authors contributed equally to this work. which are more expensive, present a higher level of side effects and have limited effectiveness. ${ }^{1}$ Therefore, there is an urgent need for innovative treatment options, which should be more effective and tolerable, for drug-susceptible and drug-resistant TB, including latent and dormant bacilli forms. ${ }^{2}$

Mtb is particularly susceptible to first-line INH drug; however, resistant strains have been reported since its early introduction for TB therapy. ${ }^{3} \mathrm{INH}$ is a pro-drug that must be activated by the mycobacterial katG-encoded catalase-peroxidase enzyme ( $\mathrm{katG})$, in the presence of manganese ions, $\mathrm{NAD}(\mathrm{H})$ and oxygen ${ }^{4-6}$ The katG-activated INH forms a covalent adduct with an $\mathrm{NAD}(\mathrm{H})$ cofactor, the isonicotinic acyl-NAD $(\mathrm{H})$, which has been shown to be a slow, tight-binding competitive inhibitor of wild-type (WT) Mycobacterium tuberculosis 2-trans-enoyl-ACP(CoA) 
reductase $(M t \operatorname{Inh} A))^{7,8}$ This enzyme, encoded by the InhA gene, belongs to the type II fatty acid synthase system (FAS-II) and catalyzes the NADH-dependent reduction of long-chain 2-trans-enoyl-ACP(CoA) substrates. The catalyzed conversion is the last reductive step of the elongation of mycolic acids, which have been considered the hallmark constituents of mycobacterial cell wall. ${ }^{9}$ Inhibition of this enzyme by the isonicotinic acyl-NAD $(\mathrm{H})$ adduct leads to the interruption of mycolic acid biosynthesis conducing to mycobacterial cell death. ${ }^{10,11}$ It is noteworthy that the main molecular mechanisms of resistance to INH have been related to gene mutations in katG and InhA or its promoter region. The prevention of the activation of INH by the gene mutation $\mathrm{S} 315 \mathrm{~T}$ in katG has been found in up to $94 \%$ of the INH-resistant clinical isolates associated with high-level resistance. ${ }^{12,13}$ Importantly, as mutations of the katG gene are the most common mechanism of resistance to INH, compounds that inhibit InhA without katG activation tend to be active against the majority of INH-resistant strains. ${ }^{14-16}$

Within this context, our research groups have described the pentacyano(isoniazid)ferrate(II) complex (IQG607), which is a slow-onset inhibitor of WT MtInhA enzyme activity, with a true overall dissociation constant of $70 \mathrm{nmol} \mathrm{L}^{-1}$ (Figure 1). ${ }^{17,18}$ Additionally, this compound is a slow-onset inhibitor of INH-resistant I21V, S94A and I47T InhA mutants, with overall dissociation constants similar to WT MtInhA. ${ }^{19}$ IQG607's mechanism of action has been hypothesized as an intramolecular electron transfer from the metallic center by a mechanism of self-activation, which favors a carbonyl-centered radical without katG participation. ${ }^{20}$ It is important to mention that the broad uses of metals and the importance of their complexes in the medical area has increased over the years. ${ }^{21}$ Metal-based complexes have showed advantages over small organic compounds such as improved aqueous solubility, controlled release, optimized pharmacokinetic parameters, specific tumor delivery and long-term anticancer efficiency prompting us to keep trying to develop a metal-containing anti-TB drug. ${ }^{21}$

Herein, some IQG607 analogs were synthesized and evaluated as possible inhibitors of MtInhA-catalyzed reactions. The enhancement of the electron density on the hydrazide group could improve the stability of the proposed radical and, hopefully, lead to better MtInhA-inhibition properties. First, the synthesis of isonicotinoylhydrazone precursors was performed through an ultrasoundassisted method. Afterward, isonicotinoylhydrazones were used for synthesizing novel pentacyanoferrate(II)isonicotinoylhydrazones, which were evaluated as inhibitors of the catalytic activity of MtInhA and the growth of the M. tuberculosis H37Rv strain. Finally, the intracellular activity of the compounds in a macrophage model of Mtb infection was also described.

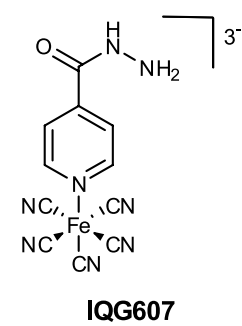

Figure 1. Chemical structure of pentacyano(isoniazid)ferrate(II) (IQG607).

\section{Results and Discussion}

First, isonicotinoylhydrazones 3a-e were synthesized by condensation reactions between isoniazid (1) and aldehydes 2a-e using an ultrasound-mediated synthetic protocol (Scheme 1). In general, sonochemistry can provide important advantages over conventional thermal heating procedures, including generation of the products under milder and faster conditions with improved yields and purities. ${ }^{22,23}$ Moreover, ultrasound-assisted techniques have been used in medicinal chemistry programs to accelerate the synthesis of drug-like compounds in accordance with green chemistry concepts. In particular, isonicotinoylhydrazones have been synthesized employing ultrasound and conventional thermal heating protocols. ${ }^{24,25}$ In these procedures, the products were obtained with $87-99 \%$ yields after sonication of reaction mixtures by $40-80$ min using an ultrasonic bath. ${ }^{24,25}$ By contrast, conventional thermal heating furnished the isonicotinoylhydrazones with 73-97\% yields after reflux for 6-8 $\mathrm{h} \cdot{ }^{24,25}$

The synthesis of hydrazones 3a-e was accomplished in the presence of $10 \mathrm{~mol} \%$ of acetic acid $(\mathrm{AcOH})$ after sonication for $15 \mathrm{~min}$, leading to the products in $78-98 \%$ yields (Scheme 1). Although water was also evaluated as a solvent in the sonochemical method, better yields were obtained with ethanol (see Supplementary Information (SI) section). Comparing both solvents, the yields were, on average, $30 \%$ higher using $2.5,5.0$ or $10.0 \mathrm{~mol} \%$ of catalyst in ethanol (Scheme S1 in the SI section). The compounds 3a-e were obtained in elevated purity and, thus, utilized in the subsequent reaction step without requiring any further purification. Comparing with already reported ultrasound metodology, the disparity in reaction times may be related to differences in power and form of energy transfer between the used equipment. Pentacyanoferrate(II)-isonicotinoylhydrazones 4a-e were prepared by a similar procedure used before for the 


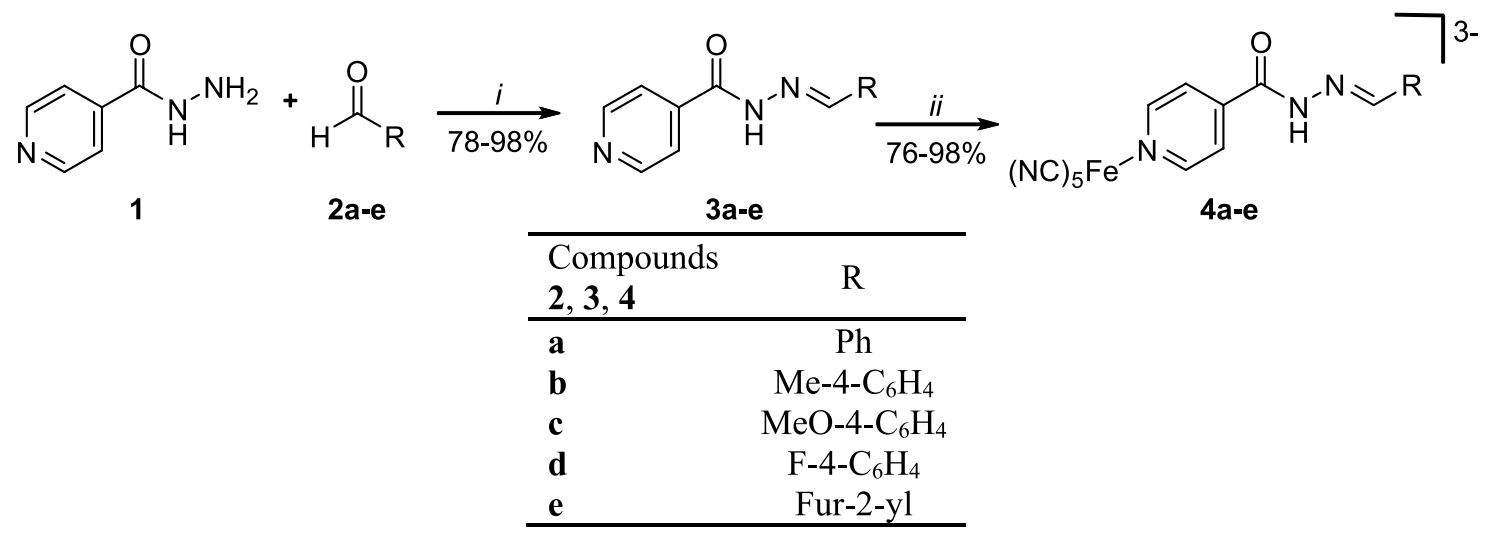

Scheme 1. Conditions: (i) $\mathrm{AcOH}(10 \mathrm{~mol} \%)$, ))), EtOH, $15 \mathrm{~min}$; (ii) $\left[\mathrm{Fe}(\mathrm{CN})_{5}\left(\mathrm{NH}_{3}\right)\right]^{3-}, \mathrm{H}_{2} \mathrm{O}, 25^{\circ} \mathrm{C}, 10 \mathrm{~h}$.

lead compound IQG607. 17,26 Aminpentacyanoferrate(II) $\left[\mathrm{Fe}(\mathrm{CN})_{5}\left(\mathrm{NH}_{3}\right)\right]^{3-}$ was synthesized from sodium nitroprusside dissolved in ammonium solution followed by $\mathrm{NH}_{3}$ gas bubbling into the reaction mixture, in accordance with a previously described protocol. ${ }^{26}$ The complexes $4 \mathbf{a}-\mathbf{e}$ were obtained from the reaction between hydrazones 3a-e and aminpentacyanoferrate(II) in water, at room temperature for $10 \mathrm{~h}$, with yields of $76-98 \%$ (Scheme 1). The $E$-stereochemistry of imine-double bond was assigned for both series of compounds based on the magnitude of the imine-proton chemical shifts. ${ }^{27}$

The pentacyanoferrate(II)-isonicotinoylhydrazones 4a-e were evaluated in line with previous studies describing the inhibitory activity of IQG607 on the reaction catalyzed by $M t \operatorname{InhA} .{ }^{17}$ It is noteworthy that coupling of the pentacyanoferrate(II) group alters the physicochemical properties of compounds, such as aqueous solubility, polarizability and reactivity. ${ }^{20}$ These chemical features are directly linked with the satisfactory pharmacokinetic profile, intermolecular binding and toxicological behavior of drug candidates. It is important to mention that compounds 3a-e did not inhibit the $M t I n h A$ activity (data not shown). By contrast, incubation of the enzyme with compounds 4a-e in the presence and in the absence of NADH resulted in time-dependent inactivation. Notably, this has become a desirable feature for chemical compounds in drug discovery research because, unlike classical enzymatic inhibitors, accumulation of the substrate for the enzyme cannot reverse time-dependent inhibition processes. ${ }^{28}$ The values of the observed first-order rate constants $\left(k_{\mathrm{obs}}\right)$ indicated that these compounds required no activation by mycobacterial katG as they were able to directly inhibit $M t \operatorname{InhA}$ (Table 1). For purposes of comparison, the $k_{\text {obs }}$ value for IQG607 was also determined. For the lead compound, $k_{\mathrm{obs}}$ was $0.89 \mathrm{~min}^{-1}$, which is different from a previously described value ${ }^{17}$ because of the different final concentration of the inhibitor. Among the synthesized series, $\mathbf{4 a}$ and $\mathbf{4 e}$ presented the lowest inhibition activities, with $k_{\mathrm{obs}}$ values of 0.38 and $0.53 \mathrm{~min}^{-1}$, respectively. By contrast, compounds $\mathbf{4 b}$ and $\mathbf{4 c}$ were more effective than IQG607, with $k_{\text {obs }}$ of 2.00 and $1.66 \mathrm{~min}^{-1}$, respectively. These values represent increments of 2.2 and 1.8-fold in the $M t \operatorname{InhA}$ inhibition rate constant compared with IQG607. Interestingly, compound $\mathbf{4 d}$ was the most effective, presenting a $k_{\mathrm{obs}}$ value of $9.4 \mathrm{~min}^{-1}$ with $\mathrm{t}_{1 / 2}$ of $0.07 \mathrm{~min}$ in the absence of NADH (Table 1). Compared with the lead complex, IQG607, 4d increased more than ten-fold the MtInhA inhibition rate constant. These findings reveal that the presence of a 4-fluoro substituent appears to favorably alter the inhibitory features of the synthesized complexes. Notably, compounds with bulkier moieties in the region of the aromatic ring, such as $\mathbf{4 b}(\mathrm{R}=\mathrm{Me})$ and $\mathbf{4 c}(\mathrm{R}=\mathrm{OMe})$, were more effective than non-substituted 4a or furan-2-yl substituted $\mathbf{4 e}$. Moreover, the inhibitory activity of IQG607 was similar to that of the compounds with smaller molecular volumes. Indeed, previous works have reported the importance of bulky and hydrophobic moieties for MtInhA inhibition. ${ }^{29}$ However, further studies are needed to clarify the structure-activity relationship for this class of anti-TB drug candidates.

The in vitro inactivation of $M t \operatorname{InhA}$ by the compounds 4a-e did not require the presence of the NADH cofactor, such as reported for IQG607. ${ }^{17}$ This can be observed in the higher value of $k_{\mathrm{obs}}$ when $10 \mu \mathrm{mol} \mathrm{L} \mathrm{L}^{-1}$ of $\mathrm{NADH}$ was pre-incubated with the compounds and $M t \operatorname{InhA}$ (Table 1). Moreover, this finding suggests that the evaluated complexes could interact with $M t \operatorname{InhA}$ at the $\operatorname{NAD}(\mathrm{H})$ binding site. Together, these results indicate that the mode of action of the metal-based compounds synthesized in this work is similar to that of IQG607, which exhibits a slow-binding inhibition profile and appears to act as a competitive inhibitor for both enzyme substrates, NADH and 2-trans-dodecenoyl-CoA (DD-CoA). ${ }^{17,19}$

In particular, the aqueous solubility of the pentacyanoferrate(II)-containing compounds was 
Table 1. Observed first-order rate constant for the pentacyanoferrate(II)-isonicotinoylhydrazones 4a-e

\begin{tabular}{|c|c|c|c|c|}
\hline \multirow{2}{*}{ Compound } & \multicolumn{2}{|c|}{$k_{\mathrm{obs}} / \mathrm{min}^{-1}$} & \multicolumn{2}{|c|}{$\mathrm{t}_{1 / 2} / \min$} \\
\hline & $0 \mu \mathrm{mol} \mathrm{L}{ }^{-1} \mathrm{NADH}$ & $10 \mu \mathrm{mol} \mathrm{L}{ }^{-1} \mathrm{NADH}$ & $0 \mu \mathrm{mol} \mathrm{L}{ }^{-1} \mathrm{NADH}$ & $10 \mu \mathrm{mol} \mathrm{L}{ }^{-1} \mathrm{NADH}$ \\
\hline $4 a$ & $0.38 \pm 0.03$ & $0.024 \pm 0.002$ & $1.83 \pm 0.17$ & $28.8 \pm 2.8$ \\
\hline $4 b$ & $2.00 \pm 0.16$ & $0.318 \pm 0.02$ & $0.35 \pm 0.02$ & $2.17 \pm 0.16$ \\
\hline $4 c$ & $1.66 \pm 0.15$ & $0.11 \pm 0.01$ & $0.42 \pm 0.03$ & $6.07 \pm 0.31$ \\
\hline $4 d$ & $9.44 \pm 1.55$ & $0.53 \pm 0.04$ & $0.07 \pm 0.01$ & $1.29 \pm 0.1$ \\
\hline $4 e$ & $0.53 \pm 0.05$ & $0.048 \pm 0.002$ & $1.31 \pm 0.13$ & $14.40 \pm 0.72$ \\
\hline IQG607 & $0.89 \pm 0.07$ & $0.22 \pm 0.01$ & $0.77 \pm 0.06$ & $3.12 \pm 0.16$ \\
\hline
\end{tabular}

$k_{\text {obs: }}$ : first-order rate constants; $\mathrm{t}_{1 / 2}$ : half-life of the first-order rate constant for enzyme inhibition.

increased compared with the isonicotinoylhydrazones. The presence of pentacyanoferrate group reduced the ClogP values, on average, 0.67 logarithmic units (Table 2). Incidentally, the complexes were solubilized in water in all experiments whereas the isonicotinoylhydrazones required dimethyl sulfoxide (DMSO) as co-solvent. The isonicotinoylhydrazones 3a-e showed minimal inhibitory concentration (MIC) values, varying in the range of 5.9 to $6.9 \mu \mathrm{mol} \mathrm{L}^{-1}$ (Table 2). Compared with isoniazid dissolved in $2.5 \%$ DMSO, the compounds were approximately 2.7 to 3.1 -fold less active against the M. tuberculosis H37Rv strain than the first-line drug. By contrast, hydrazones 3a-e presented similar activity against the bacilli compared with the lead compound IQG607, which exhibited an MIC of $7.7 \mu \mathrm{mol} \mathrm{L}^{-1}$. The pentacyanoferrate(II)-isonicotinoylhydrazones $\mathbf{4 a - c}$ and $\mathbf{4 e}$ presented MICs in the range of 6.0 to $12.4 \mu \mathrm{mol} \mathrm{\textrm {L } ^ { - 1 }}$. Interestingly, the presence of a metallic center completely altered the potency order elicited by the hydrazone precursors. Among the pentacyanoferrate(II) series, compound 4a displayed the highest activity, with an MIC of $6.0 \mu \mathrm{mol} \mathrm{L}{ }^{-1}$. It is noteworthy that the association of a metallic center attached at the pyridine ring produced a compound with an improved inhibitory capacity compared with its precursor isonicotinoylhydrazone 3a (which had an MIC of $6.9 \mu \mathrm{mol} \mathrm{L}^{-1}$ ). In addition, $4 \mathbf{a}$ was more potent than the lead compound IQG607, based on their MIC values (6.0 vs. $7.7 \mu \mathrm{mol} \mathrm{L}^{-1}$, respectively). On the other hand, the 4-fluoro-substituted complex 4d did not show antimycobacterial activity at the maximum tested concentration of $24 \mu \mathrm{mol} \mathrm{L} \mathrm{L}^{-1}$. It is important to keep in mind that this metal-based complex exhibited the most effective inhibition of $M t I n h A$ activity among the evaluated structures. This fact reinforces the known difficulty of uniting potent target inhibition with chemical properties that allow for cellular potency in anti-TB drug discovery. Moreover, as no correlation was observed between $M t I n h A$ inhibition and MIC values, further studies need to be provided to ascertain whether or not $M t \operatorname{InhA}$ is the molecular target responsible for the antimycobacterial activity presented by the compounds.

Considering their MIC values, compounds $\mathbf{4 a - c}$ and $\mathbf{4 e}$ were selected for further investigation of possible in vitro cytotoxic effects on mammalian cells using the 3-(4,5-dimethylthiazol-2-yl)-2,5-diphenyltetrazolium bromide (MTT) protocol. HaCat (human keratinocyte) and RAW 264.7 (murine macrophage) cells were used in these experiments. Cellular viability was evaluated after exposing the cell lineages to the metal-based compounds, and the results were expressed as percentages of cell viability (Table 3). The in vitro incubation of the compounds, at concentrations of 10 and $20 \mu \mathrm{mol} \mathrm{L}{ }^{-1}$, did not significantly

Table 2. ClogP values and activity of the synthesized isonicotinoylhydrazones 3a-e and pentacyanoferrate(II)-isonicotinoylhydrazones 4a-e against the M. tuberculosis H37Rv strain

\begin{tabular}{lccccc}
\hline Compound & $\mathrm{ClogP}^{\mathrm{a}}$ & $\mathrm{MIC} /(\mu \mathrm{mol} \mathrm{L})$ & Compound & $\mathrm{ClogP}^{-1}$ & $\left.\mathrm{MIC}^{\mathrm{a}}(\mu \mathrm{mol} \mathrm{L})^{-1}\right)$ \\
\hline 3a & 1.62 & 6.9 & $\mathbf{4 a}$ & 0.92 & 6.0 \\
3b & 2.12 & 6.4 & $\mathbf{4 b}$ & 1.42 & 23.5 \\
3c & 1.69 & 5.9 & $\mathbf{4 c}$ & 1.14 & 11.3 \\
3d & 1.76 & 6.3 & $\mathbf{4 d}$ & 1.06 & $>24$ \\
3e & 0.79 & 6.7 & $\mathbf{4 e}$ & 0.09 & 12.4 \\
IQG607 & -1.41 & 7.7 & $\mathrm{INH}$ & -0.67 & $1.1^{\mathrm{b}} / 2.2^{\mathrm{c}}$ \\
\hline
\end{tabular}

${ }^{\mathrm{a} C l o g P}$ calculated by ChemBioDraw Ultra version 13.0.0.3015; ' $\mathrm{INH}$ (isoniazid) dissolved in DMSO; ' INH dissolved in water. 
Table 3. Cytotoxicity effects and intracellular activity of the pentacyanoferrate(II)-isonicotinoylhydrazones $\mathbf{4 a - c}$ and $4 \mathbf{e}$ against the virulent $M$. tuberculosis H37Rv strain in macrophages

\begin{tabular}{|c|c|c|c|c|c|}
\hline \multirow{3}{*}{ Compound } & \multicolumn{4}{|c|}{ Cell viability $\pm \mathrm{SEM}^{\mathrm{a}} / \%$} & \multirow{3}{*}{$\begin{array}{c}\text { Intracellular activity }^{\mathrm{b}} \\
\text { Mean } \log _{10} \text { CFU per well } \pm \text { SEM }\end{array}$} \\
\hline & \multicolumn{2}{|c|}{ HaCat } & \multicolumn{2}{|c|}{ RAW 264.7} & \\
\hline & $10 \mu \mathrm{mol} \mathrm{L}^{-1}$ & $20 \mu \mathrm{mol} \mathrm{L}^{-1}$ & $10 \mu \mathrm{mol} \mathrm{L}-1$ & $20 \mu \mathrm{mol} \mathrm{L}-1$ & \\
\hline $4 a$ & $95 \pm 9$ & $95 \pm 7$ & $100 \pm 10$ & $95 \pm 6$ & $4.96 \pm 0.16$ \\
\hline $4 b$ & $90 \pm 6$ & $94 \pm 79$ & $97 \pm 1$ & $92 \pm 4$ & $4.94 \pm 0.15$ \\
\hline $4 c$ & $98 \pm 2$ & $98 \pm 9$ & $86 \pm 5$ & $95 \pm 5$ & $4.78 \pm 0.04^{\mathrm{d}}$ \\
\hline $4 e$ & $94 \pm 5$ & $96 \pm 5$ & $93 \pm 4$ & $99 \pm 2$ & $4.86 \pm 0.05^{\mathrm{c}}$ \\
\hline INH & - & - & - & - & $4.63 \pm 0.12^{\mathrm{d}}$ \\
\hline UNT & - & - & - & - & $5.34 \pm 0.06$ \\
\hline
\end{tabular}

${ }^{\mathrm{a}}$ Untreated control wells were considered as $100 \%$ of cell viability. ${ }^{\mathrm{b}}$ Data are expressed as the means \pm standard error (SEM) of triplicates for each compound tested at $10 \mu \mathrm{mol} \mathrm{L}{ }^{-1} ;{ }^{\mathrm{c}} p<0.05 ;{ }^{\mathrm{d}} p<0.01$ compared with the untreated group (Dunnett post-test). HaCat: human keratinocyte cells; RAW 264.7: murine macrophage cells; INH: isoniazid; UNT: untreated.

affect the cell viability of either of the cell lines tested, indicating an apparent low toxicity of the compounds to mammalian cells and selectivity for Mtb at evaluated concentrations.

The favorable features elicited by the compounds prompted us to investigate their intracellular activity in a macrophage model of Mtb infection. The INH $\left(10 \mu \mathrm{mol} \mathrm{L} \mathrm{L}^{-1}\right)$-treated group showed a decrease of $0.71 \log _{10}(p<0.01)$ in the CFU counts (colony forming units) compared with the untreated control (Table 3). Unfortunately, exposing infected macrophages to the compounds $\mathbf{4 a}$ and $\mathbf{4 b}$ did not show a statistically significant reduction in the CFU counts. It is important to mention that compound 4a presented the best MIC value of this series, indicating a possible difficulty for the molecule in crossing cellular and mycobacterial barriers to inhibit Mtb growth inside macrophages. By contrast, treatment with the compounds $\mathbf{4} \mathbf{c}$ and $\mathbf{4 e}$ resulted in significant reductions in the CFU counts compared with the untreated control (Table 3). Notably, compound $\mathbf{4 c}$ exhibited intracellular activity similar to INH, with no statistical difference compared with the INH CFU counts. This finding indicates that compound $\mathbf{4 c}$, even with higher MIC value than INH, was able to inhibit intracellular mycobacteria growth with similar potency to that elicited by first-line drug. Together with increment of 1.8-fold in MtInhA inhibition rate constant compared with the lead IQG607, the coordination complex $\mathbf{4} \mathbf{c}$ becomes a promising starting point of a new class of metallo-based drug candidates for the tuberculosis treatment.

\section{Conclusions}

Herein, we have proposed an improved method for synthesizing isonicotinoylhydrazones using ultrasound energy. This environmentally friendly synthetic protocol produced the compounds with satisfactory to elevated yields, shorter reaction times and high purity compared with conventional thermal heating protocols. Furthermore, pentacyanoferrate(II)-isonicotinoylhydrazones were also synthesized in satisfactory to high yields (76-98\%) and with good purity. The coordination complexes were able to inhibit $M t$ InhA in a time-dependent manner at comparable or greater velocities than the lead compound IQG607. Additionally, the compounds showed activity against drug-sensitive M. tuberculosis $\mathrm{H} 37 \mathrm{Rv}$ with no apparent toxicity for mammalian cells. Finally, some pentacyanoferrate(II)-isonicotinoylhydrazones presented activity in a macrophage-infected model, and one of them exhibited similar activity to that of the first-line drug isoniazid. Altogether, these results indicate that this class of compounds may furnish candidates for future progression from basic research to pre-clinical pharmacological and, if feasible, toxicological studies aiming at new anti-TB agents. Studies to try to understand the structural requirements for $M t I n h A$ inhibition and cellular potency are in progress and these results will be communicated in the future.

\section{Experimental}

\section{Synthesis and structure: apparatus and analysis}

All commercially available solvents and reagents were obtained from commercial suppliers and used without further purification. The sonochemical method for the synthesis of isonicotinoylhydrazones was carried out with a standard probe $(25 \mathrm{~mm})$ connected to a 1500 Watt Sonics Vibra-Cell ultrasonic processor (Newtown, Connecticut, USA) equipped with integrated temperature control. The device operates at $20 \mathrm{kHz}$, and the amplitude was set to 
$20 \%$. In all experiments, the temperature was raised to $77-81{ }^{\circ} \mathrm{C}$ (ethanol) or $88-94{ }^{\circ} \mathrm{C}$ (water) after sonication for 5-8 min and was maintained at this level until the end of the reaction times. Melting points were measured using a Microquímica MQAPF-302 apparatus. ${ }^{1} \mathrm{H}$ nuclear magnetic resonance (NMR) spectra were acquired on an Anasazi EFT-60 or Varian 400 spectrometer $\left({ }^{1} \mathrm{H}\right.$ at 60.13 or $400.13 \mathrm{MHz}$, respectively). ${ }^{13} \mathrm{C}$ NMR spectra were acquired on a Varian 400 spectrometer $\left({ }^{13} \mathrm{C}\right.$ at $\left.100.6 \mathrm{MHz}\right)$ (Federal University of Rio Grande do Sul, UFRGS/Brazil). DMSO- $d_{6}$ or $\mathrm{D}_{2} \mathrm{O}$ were used as the solvent in $5 \mathrm{~mm}$ sample tubes. Splitting patterns were designated as follows: $\mathrm{s}$, singlet; d, doublet; m, multiplet. High-resolution mass spectra (HRMS) were obtained for all compounds on an LTQ Orbitrap Discovery mass spectrometer (Thermo Fisher Scientific, Bremen, Germany). This hybrid system combines an LTQ XL linear ion-trap mass spectrometer and an Orbitrap mass analyzer. The experiments were performed via direct infusion of the sample in $\mathrm{MeOH}-\mathrm{H}_{2} \mathrm{O}$ (1:1) with $0.1 \%$ formic acid (flow rate $10 \mu \mathrm{L} \mathrm{min}{ }^{-1}$ ) in positive-ion mode using electrospray ionization (ESI). Elemental composition calculations were executed using the specific tool included in the Qual Browser module of the Xcalibur (Thermo Fisher Scientific, release 2.0.7) software. Cyclic voltammetry measurements were obtained with a 757 VA Computrace (Metrohm, Switzerland). Voltammograms were acquired using a glassy carbon electrode as the working electrode and a platinum auxiliary electrode in $0.1 \mathrm{~mol} \mathrm{~L}^{-1} \mathrm{KCl}$ solution at $25^{\circ} \mathrm{C}$. Fourier transform infrared (FTIR) spectra were recorded using a universal attenuated total reflectance (UATR) attachment on a PerkinElmer Spectrum 100 spectrometer in the wavenumber range of $650-4000 \mathrm{~cm}^{-1}$ at a resolution of $4 \mathrm{~cm}^{-1}$. The $\mathrm{CHN}$ elemental analyses were performed on a PerkinElmer $2400 \mathrm{CHN}$ elemental analyzer (São Paulo University, USP/Brazil).

General procedure for synthesis of isonicotinoylhydrazones 3a-e

Isoniazid (1) $(0.144 \mathrm{~g}, 1.05 \mathrm{mmol})$ and the appropriate aldehyde 2a-e (1.0 mmol) were mixed in ethanol $(20 \mathrm{~mL})$ in the presence of $10 \mathrm{~mol} \%$ of acetic acid as catalyst in a $50 \mathrm{~mL}$ beaker. The reaction mixture was sonicated for 15 min using an ultrasonic probe. After cooling to room temperature, the solvent was evaporated under reduced pressure. The obtained solids were washed with water $(4 \times 10 \mathrm{~mL})$ under vigorous stirring followed by centrifugation. Afterward, the products were dried under reduced pressure and isolated in satisfactory purity without need of subsequent purification steps.
(E)-N'-Benzylideneisonicotinohydrazide (3a)

Yield: 95\%; mp 190-191 ${ }^{\circ} \mathrm{C}\left(194-196{ }^{\circ} \mathrm{C}\right) ;{ }^{24} \mathrm{IR}$ (UATR) $v / \mathrm{cm}^{-1}$ 3,198 (NH), 3,027 (CH), 1,682 (C=O), 1,562 $(\mathrm{C}=\mathrm{N}), 1,282,1,149,766,684 ;{ }^{1} \mathrm{H}$ NMR $(60.1 \mathrm{MHz}$, DMSO- $\left.d_{6}\right) \delta$ 7.48-7.91 (m, 7H, Ar-H, Py-H*), $8.52(\mathrm{~s}, 1 \mathrm{H}$, vinylic-H), 8.81 (d, 2H, J 5.9 Hz, Py-H), 12.08 (s, 1H, NH); ${ }^{13} \mathrm{C}$ NMR (100.6 MHz, DMSO- $d_{6}$ ) $\delta 121.5,128.8,130.3$, 134.0, 140.5, 149.1, 150.3, 161.6; HRMS (FTMS + pESI) $m / z$, calcd. for $\mathrm{C}_{13} \mathrm{H}_{11} \mathrm{~N}_{3} \mathrm{O}[\mathrm{M}+\mathrm{H}]^{+}:$226.0975, found: 226.0957; *Py-H: pyridine hydrogens.

(E)-N'-(4-Methylbenzylidene)isonicotinohydrazide (3b)

Yield: $85 \%$; mp $188-190{ }^{\circ} \mathrm{C}\left(190-192{ }^{\circ} \mathrm{C}\right) ;{ }^{30} \mathrm{IR}$ (UATR) $v / \mathrm{cm}^{-1} 1,651(\mathrm{C}=\mathrm{O}), 1,550(\mathrm{C}=\mathrm{N}), 1,301,814,686$; ${ }^{1} \mathrm{H}$ NMR $\left(60.1 \mathrm{MHz}\right.$, DMSO- $\left.d_{6}\right) \delta 2.35\left(\mathrm{~s}, 3 \mathrm{H}, \mathrm{CH}_{3}\right), 7.29$ (d, $2 \mathrm{H}, J 7.5 \mathrm{~Hz}, \mathrm{Ar}-\mathrm{H}), 7.68$ (d, 2H, J 7.8 Hz, Ar-H), 7.85 (d, 2H, J $6.0 \mathrm{~Hz}, \mathrm{Py}-\mathrm{H}^{*}$ ), 8.47 (s, 1H, vinylic-H), 8.81 (d, 2H, J $5.6 \mathrm{~Hz}, \mathrm{Py}-\mathrm{H}), 12.02$ (s, 1H, NH); ${ }^{13} \mathrm{C}$ NMR $\left(100.6 \mathrm{MHz}, \mathrm{DMSO}-d_{6}\right) \delta 21.0,121.5,127.2,129.4,131.3$, 140.2, 140.5, 149.1, 150.3, 161.5; HRMS (FTMS + pESI) $m / z$, calcd. for $\mathrm{C}_{14} \mathrm{H}_{13} \mathrm{~N}_{3} \mathrm{O}[\mathrm{M}+\mathrm{H}]^{+}:$240.1131, found: 240.1136; *Py-H: pyridine hydrogens.

(E)- $N$ '-(4-Methoxybenzylidene)isonicotinohydrazide (3c)

Yield: $98 \%$; $\mathrm{mp} 166-168^{\circ} \mathrm{C}\left(170-173{ }^{\circ} \mathrm{C}\right) ;{ }^{24} \mathrm{IR}$ (UATR) $v / \mathrm{cm}^{-1}$ 3,202 (NH), 3,047 (CH), 1,654 (C=O), 1,596 (C=N), $1,512,1,256,830,688 ;{ }^{1} \mathrm{H}$ NMR (60.1 MHz, DMSO- $\left.d_{6}\right)$ $\delta 3.83$ (s, 3H, OMe), 7.04 (d, 2H, J 8.8 Hz, Ar-H), 7.65-7.89 (m, 4H, Ar-H, Py-H*), 8.44 (s, 1H, vinylic-H), 8.80 (d, 2H, $J 6.1 \mathrm{~Hz}, \mathrm{Py}-\mathrm{H}), 11.95$ (s, $1 \mathrm{H}, \mathrm{NH}) ;{ }^{13} \mathrm{C}$ NMR $(100.6 \mathrm{MHz}$, DMSO- $\left.d_{6}\right) \delta 55.3,114.3,121.5,126.5,128.9,140.6,148.9$, 150.3, 161.1, 161.4; HRMS (FTMS + pESI) $\mathrm{m} / \mathrm{z}$, calcd. for $\mathrm{C}_{14} \mathrm{H}_{13} \mathrm{~N}_{3} \mathrm{O}_{2}[\mathrm{M}+\mathrm{H}]^{+}:$256.1081, found: 256.1076; *Py-H: pyridine hydrogens.

\section{(E)-N'-(4-Fluorobenzylidene)isonicotinohydrazide (3d)}

Yield: $78 \%$; mp $193-195^{\circ} \mathrm{C}\left(216-220^{\circ} \mathrm{C}\right) ;{ }^{31} \mathrm{IR}$ (UATR) $\mathrm{v} / \mathrm{cm}^{-1} 3,185(\mathrm{NH}), 2,955(\mathrm{CH}), 1,654(\mathrm{C}=\mathrm{O}), 1,551(\mathrm{C}=\mathrm{N})$, $1,508,1,231,835,687 ;{ }^{1} \mathrm{H}$ NMR $\left(60.1 \mathrm{MHz}\right.$, DMSO- $\left.d_{6}\right)$ $\delta$ 7.17-7.46 (m, 2H, Ar-H), 7.72-7.89 (m, 4H, Ar-H, Py-H*), 8.49 (s, 1H, vinylic-H), 8.81 (d, 2H, J 5.6 Hz, Py-H), 12.09 $(\mathrm{s}, 1 \mathrm{H}, \mathrm{NH}) ;{ }^{13} \mathrm{C}$ NMR $\left(100.6 \mathrm{MHz}, \mathrm{DMSO}-d_{6}\right) \delta 115.8(\mathrm{~d}$, $J 21 \mathrm{~Hz}), 121.4,129.3(\mathrm{~d}, J 8.7 \mathrm{~Hz}), 130.6(\mathrm{~d}, J 2.5 \mathrm{~Hz})$, 140.4, 147.9, 150.2, 162.7 (d, J $230 \mathrm{~Hz}$ ), 164.4; HRMS (FTMS + pESI) $m / z$, calcd. for $\mathrm{C}_{13} \mathrm{H}_{10} \mathrm{FN}_{3} \mathrm{O}[\mathrm{M}+\mathrm{H}]^{+}$: 244.0881, found: 244.0876; *Py-H: pyridine hydrogens.

(E)- $N^{\prime}$-(Thiophen-2-ylmethylene)isonicotinohydrazide (3e) Yield: $92 \%$; mp $170-172{ }^{\circ} \mathrm{C}\left(165-167^{\circ} \mathrm{C}\right) ;{ }^{25} \mathrm{IR}$ (UATR) $\mathrm{v} / \mathrm{cm}^{-1} 3,268(\mathrm{NH}), 3,121(\mathrm{CH}), 1,646(\mathrm{C}=\mathrm{O}), 1,618,1,533$ $(\mathrm{C}=\mathrm{N}), 1,351,1,291,839,764,681$; ${ }^{1} \mathrm{H}$ NMR $(60.1 \mathrm{MHz}$, 
DMSO- $\left.d_{6}\right) \delta 6.67(\mathrm{Br}, 1 \mathrm{H}$, Fur-H*), $7.00(\mathrm{~d}, 1 \mathrm{H}, J 3.3 \mathrm{~Hz}$, Fur-H), 7.78-7.88 (m, 3H, Fur-H, Py-H*), 8.38 (s, 1H, vinylic-H), $8.80(\mathrm{~d}, 2 \mathrm{H}, J 5.8 \mathrm{~Hz}, \mathrm{Py}-\mathrm{H}), 12.02(\mathrm{~s}, 1 \mathrm{H}$, $\mathrm{NH}) ;{ }^{13} \mathrm{C}$ NMR $\left(100.6 \mathrm{MHz}, \mathrm{DMSO}-d_{6}\right) \delta 112.2,114.2$, 120.9, 121.4, 138.6, 145.5, 150.1, 150.3, 163.8; HRMS (FTMS + pESI) $m / z$, calcd. for $\mathrm{C}_{11} \mathrm{H}_{9} \mathrm{~N}_{3} \mathrm{O}_{2}[\mathrm{M}+\mathrm{H}]^{+}$: 216.0768, found: 216.0773; *Fur-H: fur-2-yl hydrogens; *Py-H: pyridine hydrogens.

\section{General procedure for synthesis of compounds 4a-e}

The coordination complexes 4 were prepared by a two-step synthetic procedure with minor modifications from an earlier reported method described for the isoniazid ligand (IQG607). ${ }^{17,23}$ All synthetic processes were carried out at controlled temperature and protected from light. In a $250 \mathrm{~mL}$ flask, $0.298 \mathrm{~g}(1 \mathrm{mmol})$ of sodium nitroprusside was dissolved in $10 \mathrm{~mL}$ of ammonium solution (25\%) with stirring. $\mathrm{NH}_{3}$ gas was bubbled into the reaction mixture for $4 \mathrm{~h}$ on an ice bath at temperatures ranging from -1 to $-2{ }^{\circ} \mathrm{C}$. After the reaction was complete, a yellow solid was formed, characteristic of aminpentacyanoferrate(II) as an intermediate compound. ${ }^{23}$ Lastly, the solid formed was filtered off, washed with absolute ethanol, and dried under reduced pressure. Without any further purification, $0.326 \mathrm{~g}(1 \mathrm{mmol})$ of aminpentacyanoferrate(II) $\left(\mathrm{Na}_{3}\left[\mathrm{Fe}(\mathrm{CN})_{5}\left(\mathrm{NH}_{3}\right)\right] \cdot 3 \mathrm{H}_{2} \mathrm{O}\right)$ was dissolved in $8 \mathrm{~mL}$ of ultrapure water under argon flow. To the resulting solution, the respective isonicotinoylhydrazone $(3 \mathrm{mmol})$ was added and the mixture was stirred for $10 \mathrm{~h}$ at $25^{\circ} \mathrm{C}$. Subsequently, the reaction mixture was filtered and the resulting solution was added dropwise to another vessel containing $100 \mathrm{~mL}$ of cold NaI solution in ethanol $(1: 10, \mathrm{~m} / \mathrm{v})$. Because of the efficiency of the precipitation process, the flask was stored at $4{ }^{\circ} \mathrm{C}$ for at least $16 \mathrm{~h}$. Finally, the solid product was separated by centrifugation, washed with cold ethanol $(2 \times 25 \mathrm{~mL})$ and dried under reduced pressure.

\section{Pentacyano[(E)-benzylideneisonicotinohydrazide]ferrate(II)} (4a)

Yield: $94 \% ; \lambda\left(\mathrm{H}_{2} \mathrm{O}\right) / \mathrm{nm} \mathrm{456}$; IR (UATR) $v / \mathrm{cm}^{-1}$ 2,038 $(\mathrm{CN}), 1,653(\mathrm{C}=\mathrm{O}), 1,546(\mathrm{C}=\mathrm{N}), 1,295,758,690$; ${ }^{1} \mathrm{H}$ NMR (400.1 MHz, $\left.\mathrm{D}_{2} \mathrm{O}\right) \delta$ 7.24-7.36 (m, 5H, Ar-H), 7.59 (d, 2H, $J 8 \mathrm{~Hz}$, Py-H*), 8.15 (s, 1H, vinylic-H), 8.99 (d, 2H, J $4 \mathrm{~Hz}, \mathrm{Py}-\mathrm{H}) ;{ }^{13} \mathrm{C}$ NMR (100.6 MHz, $\left.\mathrm{D}_{2} \mathrm{O}\right)$ $\delta$ 120.3, 127.7, 129.0, 131.7, 132.5, 152.4, 157.3, 164.3, $174.9,179.3 ; \mathrm{E}_{1 / 2}: 390 \mathrm{mV}$ (vs. $\left.\mathrm{Ag} \mid \mathrm{AgCl}\right)$; anal. calcd. for $\mathrm{C}_{18} \mathrm{H}_{11} \mathrm{FeN}_{8} \mathrm{Na}_{3} \mathrm{O}+3 \mathrm{H}_{2} \mathrm{O}: \mathrm{C}, 40.47 ; \mathrm{H}, 3.21 ; \mathrm{N}, 20.98$, found: $\mathrm{C}, 40.33 ; \mathrm{H}, 3.09 ; \mathrm{N}, 20.56 \%$; *Py-H: pyridine hydrogens.
Pentacyano[(E)-(4-methylbenzylidene)isonicotinohydrazide] ferrate(II) (4b)

Yield: $95 \% ; \lambda\left(\mathrm{H}_{2} \mathrm{O}\right) / \mathrm{nm} \mathrm{451}$; IR (UATR) $v / \mathrm{cm}^{-1}$ 2,032 (CN), 1,626 (C=O), 1,528 (C=N), 1,265, 711, 670; ${ }^{1} \mathrm{H}$ NMR $\left(400.1 \mathrm{MHz}, \mathrm{D}_{2} \mathrm{O}\right) \delta 2.17$ (s, 3H, Me), 7.15 (d, $2 \mathrm{H}, J 8 \mathrm{~Hz}, \mathrm{Ar}-\mathrm{H}), 7.32$ (d, 2H, $\left.J 8 \mathrm{~Hz}, \mathrm{Py}-\mathrm{H}^{*}\right), 7.56$ (d, 2H, J $8 \mathrm{~Hz}, \mathrm{Ar}-\mathrm{H}), 8.15$ (s, $1 \mathrm{H}$, vinylic-H), 9.02 (d, $2 \mathrm{H}, J 8 \mathrm{~Hz}, \mathrm{Py}-\mathrm{H}) ;{ }^{13} \mathrm{C}$ NMR $\left(100.6 \mathrm{MHz}, \mathrm{D}_{2} \mathrm{O}\right) \delta 20.7$, 120.4, 127.9, 129.7, 130.0, 142.5, 152.7, 156.8, 163.1, 175.0, 179.5; $\mathrm{E}_{1 / 2}: 337 \mathrm{mV}$ (vs. Ag|AgCl); anal. calcd. for $\mathrm{C}_{19} \mathrm{H}_{13} \mathrm{FeN}_{8} \mathrm{Na}_{3} \mathrm{O}+3 \mathrm{H}_{2} \mathrm{O}: \mathrm{C}, 41.63 ; \mathrm{H}, 3.49 ; \mathrm{N}, 20.44$, found: C, 41.26; H, 3.27; N, 20.19\%; *Py-H: pyridine hydrogens.

Pentacyano[(E)-(4-methoxybenzylidene)isonicotinohydrazide]ferrate(II) (4c)

Yield: 76\%; $\lambda\left(\mathrm{H}_{2} \mathrm{O}\right) / \mathrm{nm} 450$; IR (UATR) $v / \mathrm{cm}^{-1}$ 2,031 $(\mathrm{CN}), 1,606(\mathrm{C}=\mathrm{O}), 1,513(\mathrm{C}=\mathrm{N}), 1,262,833,702$; ${ }^{1} \mathrm{H}$ NMR (400.1 MHz, $\left.\mathrm{D}_{2} \mathrm{O}\right) \delta 3.55$ (s, 3H, OMe), 6.81 (d, $2 \mathrm{H}, J 8 \mathrm{~Hz}, \mathrm{Ar}-\mathrm{H}), 7.32$ (d, 2H, J $\left.4 \mathrm{~Hz}, \mathrm{Py}-\mathrm{H}^{*}\right), 7.58$ (d, 2H, J $8 \mathrm{~Hz}, \mathrm{Ar}-\mathrm{H}), 7.99$ (s, 1H, vinylic-H), 9.06 (d, 2H, $J 4 \mathrm{~Hz}, \mathrm{Py}-\mathrm{H}) ;{ }^{13} \mathrm{C}$ NMR $\left(100.6 \mathrm{MHz}, \mathrm{D}_{2} \mathrm{O}\right) \delta 55.7,114.4$, 120.3, 125.7, 129.8, 138.1, 146.1, 157.4, 161.3, 164.6, 175.1, 179.4; $\mathrm{E}_{1 / 2}: 381 \mathrm{mV}$ (vs. $\left.\mathrm{Ag} \mid \mathrm{AgCl}\right)$; anal. calcd. for $\mathrm{C}_{19} \mathrm{H}_{13} \mathrm{FeN}_{8} \mathrm{Na}_{3} \mathrm{O}_{2}+3 \mathrm{H}_{2} \mathrm{O}: \mathrm{C}, 40.45 ; \mathrm{H}, 3.39 ; \mathrm{N}, 19.86$, found: C, 40.19; H, 3.16; N, 19.49\%; *Py-H: pyridine hydrogens.

Pentacyano[(E)-(4-fluorobenzylidene)isonicotinohydrazide] ferrate(II) (4d)

Yield: $98 \% ; \lambda\left(\mathrm{H}_{2} \mathrm{O}\right) / \mathrm{nm} 457$; IR (UATR) $v / \mathrm{cm}^{-1}$ 2,027 $(\mathrm{CN}), 1,626(\mathrm{C}=\mathrm{O}), 1,527(\mathrm{C}=\mathrm{N}), 1,263,711$; ${ }^{1} \mathrm{H}$ NMR (400.1 MHz, $\left.\mathrm{D}_{2} \mathrm{O}\right) \delta$ 7.11-7.15 (m, 2H, Ar-H), 7.40 (d, 2H, J 4 Hz, Py-H*), 7.72-7.75 (m, 2H, Ar-H), 8.25 (s, $1 \mathrm{H}$, vinylic-H), 9.02 (d, 2H, $J 8 \mathrm{~Hz}, \mathrm{Py}-\mathrm{H}) ;{ }^{13} \mathrm{C}$ NMR $\left(100.6 \mathrm{MHz}, \mathrm{D}_{2} \mathrm{O}\right) \delta 116.2,120.5,129.5,130.4,138.4$, $151.8,157.7,162.9,164.0,175.1,179.7 ; \mathrm{E}_{1 / 2}: 377 \mathrm{mV}$ (vs. Ag|AgCl); anal. calcd. for $\mathrm{C}_{18} \mathrm{H}_{10} \mathrm{FFeN}_{8} \mathrm{Na}_{3} \mathrm{O}+3 \mathrm{H}_{2} \mathrm{O}$ : C, 39.15; H, 2.92; N, 20.29, found: C, 38.91; H, 2.74; N, $20.01 \%$; *Py-H: pyridine hydrogens.

Pentacyano[(E)-(thiophen-2-ylmethylene)isonicotinohydrazide]ferrate(II) (4e)

Yield: $78 \% ; \lambda\left(\mathrm{H}_{2} \mathrm{O}\right) / \mathrm{nm} 452$; IR (UATR) $v / \mathrm{cm}^{-1} 2,034$ $(\mathrm{CN}), 1,622(\mathrm{C}=\mathrm{O}), 1,542(\mathrm{C}=\mathrm{N}), 1,296,757,686 ;{ }^{1} \mathrm{H}$ NMR $\left(400.1 \mathrm{MHz}, \mathrm{D}_{2} \mathrm{O}\right) \delta 6.44$ (s, 1H, Fur-H*), $6.77(\mathrm{~s}, 1 \mathrm{H}$, Fur-H), 7.31 (d, 2H, J 4 Hz, Py-H*), 7.50 (s, 1H, Fur-H), 8.04 (s, $1 \mathrm{H}$, vinylic-H), 8.99 (d, $2 \mathrm{H}, J \mathrm{~Hz}, \mathrm{Py}-\mathrm{H}) ;{ }^{13} \mathrm{C}$ NMR $\left(100.6 \mathrm{MHz}, \mathrm{D}_{2} \mathrm{O}\right) \delta 112.5,117.3,120.3,138.2,140.9$, $146.3,147.8,157.3,164.4,175.0,179.5 ; \mathrm{E}_{1 / 2}: 426 \mathrm{mV}$ (vs. $\mathrm{Ag} \mid \mathrm{AgCl}$ ); anal. calcd. for $\mathrm{C}_{16} \mathrm{H}_{9} \mathrm{FeN}_{8} \mathrm{Na}_{3} \mathrm{O}_{2}+3 \mathrm{H}_{2} \mathrm{O}$ : 
C, 36.66; H, 2.88; N, 21.38, found: C, 36.31; H, 2.64; N, $21.05 \%$; *Fur-H: fur-2-yl hydrogens; *Py-H: pyridine hydrogens.

\section{Biological assays}

\section{Time-dependent inhibition assays}

Expression and purification of the recombinant WT InhA from $M$. tuberculosis were performed as previously described. ${ }^{9,32}$ The protein concentration was spectrophotometrically determined by diluting $10 \mu \mathrm{L}$ of purified enzyme to $500 \mu \mathrm{L}$ in $100 \mathrm{mmol} \mathrm{L}^{-1}$ Pipes (pH 7.0) at $25^{\circ} \mathrm{C}$, assuming an extinction coefficient of $29,600 \mathrm{M}^{-1} \mathrm{~cm}^{-1}$ at $282 \mathrm{~nm}$. The substrate DD-CoA was synthesized and purified as described elsewhere., ${ }^{9,33}$ Time-dependent inactivation reactions were performed using a UV-2550 UV-Vis spectrophotometer (Shimadzu, Japan) by monitoring the oxidation of NADH to $\mathrm{NAD}^{+}$at $340 \mathrm{~nm}\left(\varepsilon_{\mathrm{NADH}}=6220 \mathrm{M}^{-1} \mathrm{~cm}^{-1}\right)$ due to the reduction of the DD-CoA substrate for a period of $60 \mathrm{~s}$ at $25^{\circ} \mathrm{C}$. The enzymatic assay was performed essentially as previously described. ${ }^{17}$ In brief, $3 \mu \mathrm{mol} \mathrm{L}{ }^{-1}$ of InhA was incubated with $500 \mu \mathrm{mol} \mathrm{L}^{-1}$ isonicotinoylhydrazone-pentacyanoferrate(II) compounds in the presence or absence of $10 \mu \mathrm{mol} \mathrm{L}^{-1}$ of NADH cofactor in $100 \mathrm{mmol} \mathrm{L}^{-1} \mathrm{Na}_{2} \mathrm{HPO}_{4} \mathrm{pH} 7.5$ buffer. Aliquots from the mixture were taken at different times, and were added to a cuvette containing $100 \mu \mathrm{mol} \mathrm{L}^{-1}$ of DD-CoA and $200 \mu \mathrm{mol} \mathrm{L}^{-1}$ of NADH with a final volume of $500 \mu \mathrm{L}$ in order to measure the remaining enzymatic activity after the incubation. It is noteworthy that stability of compounds in solution was evaluated by voltammetric methods for at least three days without any apparent modification.

The following equations were employed to determine $k_{\mathrm{obs}}$ and $\mathrm{t}_{1 / 2}$ of the inhibitors, respectively:

$v=v_{0} \mathrm{e}^{-k_{\text {obs }}}$

$\mathrm{t}_{1 / 2}=\frac{\ln 2}{k_{\text {obs }}}$

where $v$ is the remaining InhA enzyme activity at time t, $v_{0}$ is the enzyme activity at time zero, $k_{\mathrm{obs}}$ is the observed first-order rate constant for InhA inhibition, $t$ is time in seconds, and $t_{1 / 2}$ is the half-life of the first-order rate constant for enzyme inhibition.

\section{Mycobacterium tuberculosis inhibition assay}

The measurement of MIC for each tested compound was performed in 96-well U-bottom polystyrene microplates. Isoniazid (control drug) and solutions of the compounds were prepared at concentrations of $1 \mathrm{mg} \mathrm{mL}^{-1}$ either in neat DMSO (3a-k) or in water (4a-e and IQG607). They were diluted in Middlebrook 7H9 medium containing 10\% ADC (albumin, dextrose and catalase) to a concentration of $20 \mu \mathrm{g} \mathrm{mL}^{-1}$. Serial two-fold dilutions of each drug in $100 \mu \mathrm{L}$ of Middlebrook $7 \mathrm{H} 9$ medium containing $10 \%$ ADC were prepared directly in 96-well plates at concentration ranges of 10.0 to $0.02 \mu \mathrm{g} \mathrm{mL}^{-1}$. Growth controls containing no antibiotic and sterility controls without inoculation were included. MIC was determined for the M. tuberculosis H37Rv strain, which was grown in Middlebrook 7H9 containing 10\% OADC (oleic acid, albumin, dextrose and catalase) and $0.05 \%$ Tween 80 . Cells were vortexed with sterile glass beads $(4 \mathrm{~mm})$ for $5 \mathrm{~min}$ to disrupt clamps and allowed to settle for $20 \mathrm{~min}$. The supernatant was spectrophotometrically measured at an absorbance of $600 \mathrm{~nm}$. The M. tuberculosis suspension was aliquoted and stored at $-20^{\circ} \mathrm{C}$. Each suspension was appropriately diluted in Middlebrook 7H9 broth containing 10\% ADC to achieve an optical density at $600 \mathrm{~nm}$ of 0.006 , and $100 \mu \mathrm{L}$ were added to each well of the plate except for the sterility controls. For the compounds solubilized in DMSO, a final concentration of $2.5 \%$ DMSO was maintained in each well. The plates were covered, sealed with parafilm, and incubated at $37{ }^{\circ} \mathrm{C}$. After 7 days of incubation, $60 \mu \mathrm{L}$ of $0.01 \%$ resazurin solution were added to each well, and incubated for an additional $48 \mathrm{~h}$ at $37{ }^{\circ} \mathrm{C} .{ }^{34} \mathrm{~A}$ change in color from blue to pink indicated the growth of bacteria, and the MIC value was defined as the lowest drug concentration that prevented the color change. Three tests were carried out independently, and the MIC values reported here were observed in at least two assays.

\section{Cytotoxicity investigation}

Cellular viability determination after incubation with the test compounds (4a-c, $\mathbf{4 e}$ ) was performed essentially as previously described. ${ }^{35}$ RAW 264.7 and HaCat cells were grown in DMEM (Dulbecco's Modified Eagle medium) supplemented with $10 \%$ inactivated fetal bovine serum and $1 \%$ antibiotics (penicillin-streptomycin). The cells were maintained in culture bottles at $37{ }^{\circ} \mathrm{C}$ in a humidified atmosphere with $5 \% \mathrm{CO}_{2}$. Cells were seeded at $7 \times 10^{3}$ cells per well in a 96-well plate and incubated for $24 \mathrm{~h}$ to adhere. The medium was removed and replaced with $190 \mu \mathrm{L}$ DMEM, and $10 \mu \mathrm{L}$ of drug solutions, resulting in concentrations of 10 and $20 \mu \mathrm{mol} \mathrm{L}^{-1}$. After incubation for $72 \mathrm{~h}$ for HaCat and $120 \mathrm{~h}$ for RAW 264.7 cells, MTT $\left(1 \mathrm{mg} \mathrm{mL}^{-1}\right)$ was added and the resulting mixtures were incubated for $3 \mathrm{~h}$ at $37^{\circ} \mathrm{C}$ under $5 \%$ of $\mathrm{CO}_{2}$. The formazan crystals were dried at room temperature for at least $24 \mathrm{~h}$ and dissolved in DMSO. The absorbance was measured at $595 \mathrm{~nm}$ (Spectra Max M2e, Molecular Devices, USA). 
The precipitated purple formazan crystals were directly proportional to the number of live cells with active mitochondria. The percentage of cell viability for the treated groups was reported considering the control wells (untreated) as $100 \%$ of cell viability:

Cell viability $(\%)=\left(\frac{\text { absorbance of treated wells }}{\text { absorbance of control wells }}\right) \times 100$

Data were expressed as mean of cell viability \pm standard error of mean of three independent experiments performed in triplicate. The statistical analysis was performed by one-way analysis of variance, followed by the Dunnett post-test, using GraphPad Prism 5.0 (San Diego, CA, USA).

\section{Intracellular activity investigation}

To investigate the capacity of the compounds to kill intracellular mycobacteria, we tested the effects of $\mathbf{4 a - c}$ and $\mathbf{4 e}$ in a macrophage model of $M$. tuberculosis infection. The murine macrophage RAW 264.7 (obtained from Banco de Células do Rio de Janeiro (BCRJ), Brazil) was cultured in DMEM (Gibco) supplemented with $10 \%$ heat-inactivated fetal bovine serum (FBS) and 1\% penicillin-streptomycin at $37{ }^{\circ} \mathrm{C}$ with $5 \% \mathrm{CO}_{2}$. Macrophage infection procedures were performed as previously described..$^{35}$ Briefly, macrophages were seeded in 24-well culture plates at a density of 105 cells per well in DMEM (supplemented with $10 \%$ FBS) and incubated for $24 \mathrm{~h}$ at $37{ }^{\circ} \mathrm{C}$ with $5 \%$ $\mathrm{CO}_{2}$. The cells were then washed with sterile $0.9 \%$ saline solution to remove non-adherent cells. Infection of RAW 264.7 cells with M. tuberculosis H37Rv was performed at a multiplicity of infection of 1:1 (bacteria/macrophage) for $3 \mathrm{~h}$ at $37{ }^{\circ} \mathrm{C}$ with $5 \% \mathrm{CO}_{2}$. Infected RAW 264.7 cells were washed with sterile $0.9 \%$ saline solution to remove extracellular bacteria and replaced with $1 \mathrm{~mL}$ fresh DMEM (supplemented with 10\% FBS). ${ }^{35}$ Cells were then treated with the test compounds (at $10 \mu \mathrm{mol} \mathrm{L} \mathrm{L}^{-1}$ ) and with the

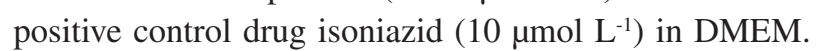
After 5 days of incubation, each well was gently washed and the infected macrophages were then lysed with $0.025 \%$ SDS dissolved in sterile $0.9 \% \mathrm{NaCl}$ solution. Lysates were serially diluted and plated on Middlebrook 7H10 Agar (Difco) supplemented with 10\% OADC. Bacterial colony formation was registered after incubation of the plates for 15 days at $37^{\circ} \mathrm{C}$. To compare cell counts, the numbers were firstly converted into logarithms of CFU $\left(\log _{10} \mathrm{CFU}\right)$. Data were evaluated by one-way analysis of variance (ANOVA), followed by the Dunnett post-test, using GraphPad Prism 5.0 (GraphPad, San Diego, CA, USA). Differences were considered significant at the $95 \%$ level of confidence. Each different drug was tested in triplicate, and the results are expressed as the log mean numbers of bacteria per well.

\section{Supplementary Information}

Supplementary information (optimization of ultrasound protocol and analytical data) is available free of charge at http://jbcs.sbq.org.br as PDF file.

\section{Acknowledgments}

This work was supported by funds from the National Institute of Science and Technology on Tuberculosis (INCT-TB), Decit/SCTIE/MS-MCT-CNPq-FNDCTCAPES (Brazil) to D. S. Santos and L. A. Basso. E. H. S. Sousa, M. M. Campos, L. A. Basso, D. S. Santos and P. Machado are Research Career Awardees of the National Research Council of Brazil (CNPq). The fellowships from CNPq (T. P. Gazzi and M. Rotta) and FAPERGS-CAPES (DOCFIX) (L. K. Martinelli and V. Rodrigues-Junior) are also acknowledged.

\section{References}

1. World Health Organizatio; Global Tuberculosis Report 2015, available from http://www.who.int/tb/publications/global_ report/en/, accessed in September, 2016.

2. Koul, A.; Arnoult, E.; Lounis, N.; Guillemont, J.; Andries, K.; Nature 2011, 469, 483.

3. Middlebrook, G.; Am. Rev. Tuber. 1952, 65, 765.

4. Zhang, Y.; Heym, B.; Allen, B.; Young, D.; Cole, S.; Nature 1992, 358, 591.

5. Banerjee, A.; Dubnau, E.; Quémard, A.; Balasubramanian, V.; Um, K. S.; Wilson, T.; Collins, D.; de Lisle, G.; Jacobs Jr., W. R.; Science 1994, 263, 227.

6. Johnsson, K.; King, D. S.; Schultz, P. G.; J. Am. Chem. Soc. 1995, 117, 5009.

7. Richa, R.; Adrian, W.; Tonge, P. J.; Proc. Natl. Acad. Sci. U. S. A. 2003, 100, 13881.

8. Rozwarski, D. A.; Grant, G. A.; Barton, D. H. R.; Jacobs Jr., W. R.; Sacchettini, J. C.; Science 1998, 279, 98.

9. Quémard, A.; Sacchettini, J. C.; Dessen, A.; Vilchèze, C.; Bittman, R.; Jacobs Jr., W. R.; Blanchard, J. S.; Biochemistry 1995, 34, 8235 .

10. Vilchèze, C.; Morbidoni, H. R.; Weisbrod, T. R.; Iwamoto, H.; Kuo, M.; Sacchettini, J. C.; Jacobs Jr., W. R.; J. Bacteriol. 2000, $182,4059$.

11. Vilchèze, C.; Wang, F.; Arai, M.; Hazbon, M. H.; Colangeli, R.; Kremer, L.; Weisbrod, T. R.; Alland, D.; Sacchettini, J. C.; Jacobs Jr., W. R.; Nat. Med. 2006, 12, 1027. 
12. Mokrousov, I.; Narvskaya, O.; Otten, T.; Limeschenko, E.; Steklova, L.; Vyshnevskit, B.; Antimicrob. Agents Chemother. 2002, 46, 1417.

13. Fenner, L.; Egger, M.; Bodmer, T.; Alpeter, E.; Zwahlen, M.; Jaton, K.; Pfyffer, G. E.; Borrel, S.; Dubius, O.; Bruderer, T.; Siegrist, H. H.; Furrer, H.; Calmy, A.; Fehr, J.; Stalder, J. M.; Ninet, B.; Böttger, E. C.; Gagneux, S.; Antimicrob. Agents Chemother. 2012, 56, 3047.

14. Musser, J. M.; Kapur, V.; Williams, D. L.; Kreiswirth, B. N.; van Soolingen, D.; van Embden, J. D.; J. Infect. Dis. 1996, 173, 196.

15. Ramaswamy, S. V.; Reich, R.; Dou, S. J.; Jasperse, L.; Pan, X.; Wanger, A.; Quitugua, T.; Graviss, E. A.; Antimicrob. Agents Chemother. 2003, 47, 1241.

16. Sullivan, T. J.; Truglio, J. J.; Boyne, M. E.; Novichenok, P.; Zhang, X.; Stratton, C. F.; Li, H. J.; Kaur, T.; Amin, A.; Johnson, F.; Slayden, R. A.; Kisker, C.; Tonge, P. J.; ACS Chem. Biol. 2006, $1,43$.

17. Oliveira, J. S.; de Sousa, E. H. S; Basso, L. A.; Palaci, M.; Dietze, R.; Santos, D. S.; Moreira, I. S.; Chem. Commun. 2004, 3,312 .

18. Oliveira, J. S.; de Souza, E. H. S.; de Souza, O. N.; Moreira, I. S.; Santos, D. S.; Basso, L. A.; Curr. Pharm. Des. 2006, 12, 2409.

19. Vasconcelos, I. B.; Meyer, E.; Sales, F. A. M.; Moreira, I. S.; Basso, L. A.; Santos, D. S.; Anti-Infect. Agents Med. Chem. 2008, 7, 50.

20. Sousa, E. H. S.; Vieira, F. G. M.; Butler, J. S.; Basso, L. A.; Santos, D. S.; Diógenes, I. C.; Lopes, L. G.; Sadler, P. J.; J. Inorg. Biochem. 2014, 140, 236.

21. Teo, R. D.; Termini, J.; Gray, H. B.; J. Med. Chem. 2016, 59, 6012.

22. Cravotto, G.; Cintas, P.; Chem. Soc. Rev. 2006, 35, 180.

23. Puri, S.; Kaur, B.; Parmar, A.; Kumar, H.; Curr. Org. Chem. 2013, 17, 1790.
24. Thomas, A. B.; Tupe, P. N.; Badhe, R. V.; Nanda, R. K.; Kothapalli, L. P.; Paradkar, O. D.; Sharma, P. A.; Deshpande, A. D.; Green Chem. Lett. Rev. 2009, 2, 23.

25. Thomas, A. B.; Sharma, P. A.; Tupe, P. N.; Badhe, R. V.; Nanda, R. K.; Kothapalli, L. P.; Paradkar, O. D.; Banerjee, A. G.; Deshpande, A. D.; Green Chem. Lett. Rev. 2011, 4, 211.

26. Basso, L. A.; Schneider, C. Z.; dos Santos, A. J. B; dos Santos, A. A.; Campos, M. M.; Souto, A. A.; Santos, D. S.; J. Braz. Chem. Soc. 2010, 21, 1384.

27. Pretsch, E.; Bühlmann, P; Affolter, C.; Structure Determination of Organic Compounds: Tables of Spectral Data, $4^{\text {th }}$ ed.; Springer-Verlag: Berlin, Germany, 2009.

28. Morrison, J. F.; Walsh, C. T.; Adv. Enzymol. Relat. Areas Mol. Biol. 1988, 61, 201.

29. Kuo, M. R.; Morbidoni, H. R.; Alland, D.; Sneddon, S. F.; Gourlie, B. B.; Staveski, M. M.; Leonard, M.; Gregory, J. S.; Janjigian, A. D.; Yee, C.; Musser, J. M.; Kreiswirth, B.; Iwamoto, H.; Perozzo, R.; Jacobs Jr., W. R.; Sacchettini, J. C.; Fidock, D. A.; J. Biol. Chem. 2003, 278, 20851.

30. Rao, V. S.; Chandra-Sekhar, K. V. G.; Synth. Commun. 2004, 34, 2153.

31. Patel, R. P.; Parikh, K. S.; Asian J. Chem. 2008, 20, 4943.

32. Basso, L. A.; Zheng, R.; Musser, J. M.; Jacobs Jr., W. R.; Blanchard, J. S.; J. Infect. Dis. 1998, 178, 769.

33. Parikh, S.; Moynihan, D. P.; Xiao, G.; Tonge, P. J.; Biochemistry 1999, 38, 13623.

34. Palomino, J. C.; Martin, A.; Camacho, M.; Guerra, H.; Swings, J.; Portaels, F.; Antimicrob. Agents Chemother. 2002, 46, 2720.

35. Rodrigues-Junior, V. S.; dos Santos, A. A.; Villela, A. D.; Belardinelli, J. M.; Morbidoni, H. R.; Basso, L. A.; Campos, M. M.; Santos, D. S.; Int. J. Antimicrob. Agents 2014, 43, 82.

Submitted: September 23, 2016

Published online: February 17, 2017

FAPERGS/CAPES has sponsored the publication of this article. 